\title{
Disseminated Saksenaea infection in an immunocompromised host associated with a good clinical outcome: a case report and review of the literature
}

\author{
N. Davidson ${ }^{1,2^{*}}$ (D, K. Campbell ${ }^{1}$, F. Foroughi ${ }^{3}$, V. Tayal ${ }^{1}$, S. Lynar ${ }^{1,4}$, L. C. Crawford ${ }^{5}$, S. E. Kidd ${ }^{5}$, R. Baird ${ }^{3}$, \\ J. Davies ${ }^{1,4+}$ and E. M. Meumann ${ }^{1,4+}$
}

\begin{abstract}
Background: Saksenaea species (spp.) are uncommon causes of mucormycosis but are emerging pathogens mostly associated with trauma and soil contamination often in immunocompetent hosts. Due to lack of sporulation in the laboratory, diagnosis and susceptibility testing is difficult so optimal treatment regimens are unknown.

Case presentation: A 67 year-old man from the Northern Territory in Australia, with a history of eosinophilic granulomatosis with polyangiitis, developed disseminated Saksenaea infection after initially presenting with symptoms consistent with bacterial pyelonephritis. Despite a delay in diagnosis; with aggressive surgical management and dual therapy with amphotericin B and posaconazole, he survived.
\end{abstract}

Conclusions: We describe an unusual case of disseminated infection with a favourable outcome to date.

Keywords: Mucormycosis, Disseminated fungal infection, Amphotericin B, Posaconazole

\section{Introduction}

Saksenaea spp. are of the order Mucorales and are infrequent causes of mucormycosis worldwide [1]. Saksenaea spp. were first described in 1953 (as Saksenaea vasiformis) from soil in India and since then have been increasingly reported in human disease causing a diverse spectrum of clinical illness mostly in tropical and subtropical regions [2]. With the advent of molecular typing, multiple species have been described within the genus including S. vasiformis, S. erythrospora, S. oblongispora, S. loutrophoriformis, S. trapezispora and S. dorisiae [3-5]. In contrast to other causes of mucormycosis, Saksenaea spp. infections often cause soft tissue or bone

\footnotetext{
* Correspondence: Natalie.davidson88@gmail.com

†'. Davies and E. M. Meumann contributed equally to this work.

'Division of Medicine, Royal Darwin Hospital, Darwin, Australia

${ }^{2}$ Sullivan and Nicolaides Pathology, Brisbane, Australia

Full list of author information is available at the end of the article
}

and joint infections in immunocompetent hosts following traumatic inoculation. Rhinosinusitis and disseminated disease are much less common but have been associated with poor outcomes with survival reported in only two previous cases of disseminated infection [1]. We describe a case of disseminated infection by a Saksenaea species with a good clinical outcome and highlight rheumatological conditions as under-recognised risk factors for mucormycosis.

\section{Case report}

A 67 year-old male living in tropical northern Australia presented with left sided abdominal pain, fever and pyuria. Computed tomography (CT) demonstrated abnormal enhancement of the lower pole of his left kidney, thickened pelvic urothelium and perinephric fat stranding. A provisional diagnosis of pyelonephritis was made,

(C) The Author(s). 2020 Open Access This article is licensed under a Creative Commons Attribution 4.0 International License, which permits use, sharing, adaptation, distribution and reproduction in any medium or format, as long as you give appropriate credit to the original author(s) and the source, provide a link to the Creative Commons licence, and indicate if changes were made. The images or other third party material in this article are included in the article's Creative Commons licence, unless indicated otherwise in a credit line to the material. If material is not included in the article's Creative Commons licence and your intended use is not permitted by statutory regulation or exceeds the permitted use, you will need to obtain permission directly from the copyright holder. To view a copy of this licence, visit http://creativecommons.org/licenses/by/4.0/ The Creative Commons Public Domain Dedication waiver (http://creativecommons.org/publicdomain/zero/1.0/) applies to the data made available in this article, unless otherwise stated in a credit line to the data. 
and he was empirically treated with intravenous ampicillin and gentamicin. His past medical history was significant for recurrent sinusitis with eosinophilia and positive perinuclear antineutrophil cytoplasmic antibodies, and he was on treatment for eosinophilic granulomatosis with polyangiitis (EGPA) with mycophenolate mofetil $750 \mathrm{mg}$ twice daily and prednisone $5 \mathrm{mg}$ daily.

Urine microscopy showed $>100 \times 10^{6}$ leucocytes/L, but no pathogen was isolated. Despite antibiotic therapy he had ongoing fevers and persistent flank pain. On day five, he developed an erythematous, indurated lesion on his left upper thigh, and the following day a similar lesion developed on his anterior abdominal wall, with the appearance of ischemic panniculitis (Fig. 1). A repeat CT scan on day 6 demonstrated absent perfusion in the lower pole of the left kidney, consistent with infarction (Fig. 2). A skin lesion biopsy was performed 2 days later, and he was commenced on methylprednisolone as treatment for presumed vasculitis. Twenty-four hours later, culture of the skin biopsy demonstrated growth of a fungus with the appearance of an organism of the order Mucorales on Sabouraud dextrose agar at $30^{\circ}$ and $37^{\circ} \mathrm{C}$. He was commenced on intravenous (IV) liposomal amphotericin B $8 \mathrm{mg} / \mathrm{kg}$ daily for treatment of presumed disseminated mucormycosis, and both skin lesions were extensively debrided. Intraoperatively, panniculitis with necrosis was found to extend to the deep fascia. Histologic examination showed fungal hyphae with angioinvasion and infarction of subcutaneous tissue (Fig. 3a). In light of this, all immunosuppression was ceased. Four

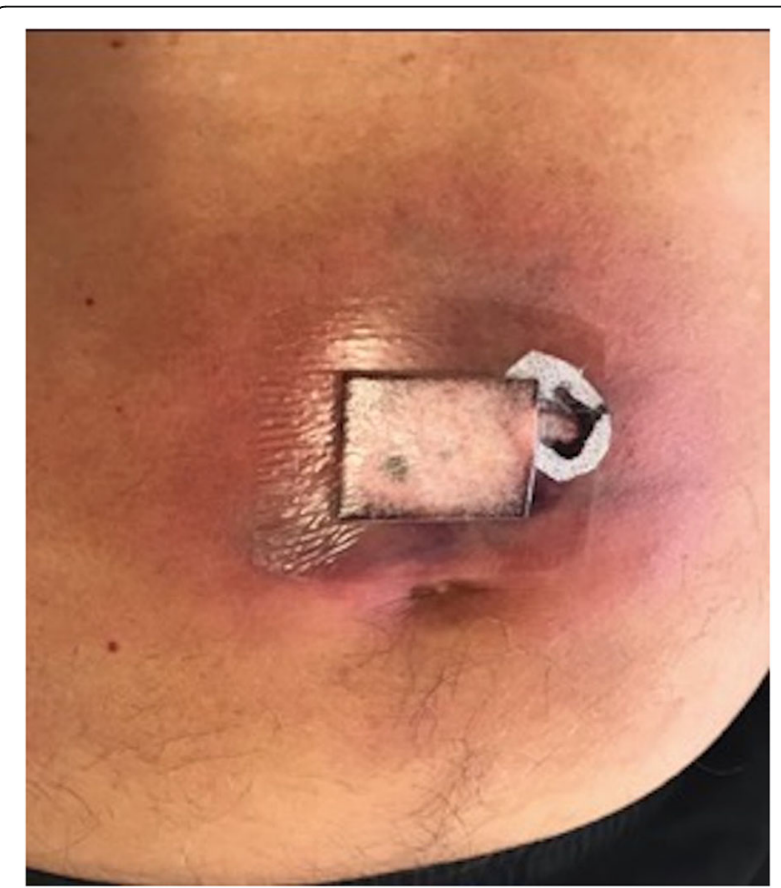

Fig. 1 Abdominal wall lesion

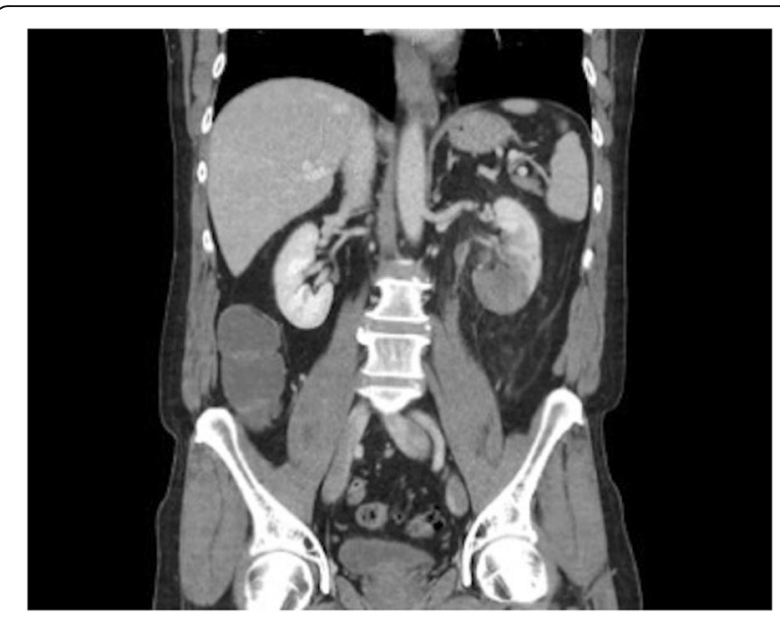

Fig. 2 CT scan demonstrating absence of perfusion in the lower pole of the left kidney

days later the patient underwent a left nephrectomy, and histologic examination of the kidney revealed necrosis with aseptate, branching hyphae consistent with organisms of the order Mucorales (Fig. 3b).

Fungal microscopy with calcofluor staining following $10 \%$ potassium hydroxide $(\mathrm{KOH})$ digestion of renal tissue confirmed the presence of wide ribbon-like aseptate fungal hyphae consistent with zygomycete infection. Tissue was cultured on Sabouraud's dextrose agar which grew a white cottony fungus at 30,37 and $40^{\circ} \mathrm{C}$ on day 3 . The isolate was referred to the National Mycology Reference Centre, where the fungus was identified as Saksenaea species (sp.) via sequencing of the internal transcribed spacer (ITS15.8S-ITS2) region of the ribosomal deoxyribonucleic acid (DNA) and Nucleotide Basic Local Alignment Search Tool (BLASTn) comparison to publicly accessible sequence databases. This demonstrated 93 and $91 \%$ sequence similarity to S. trapezispora and S. oblongispora Type material, respectively, in both the National Center for Biotechnology Information (NCBI) database (https:// blast.ncbi.nlm.nih.gov/) and the Westerdijk Fungal Biodiversity Institute database (http://www.wi.knaw.nl/Collections/BioloMICSSequences.aspx) [6], and $81 \%$ similarity to $S$. vasiformis using the International Society of Human and Animal Mycology (ISHAM) barcoding database (http://its.mycologylab.org/). This was considered insufficient for definitive species identification. Further investigation of the species identification, including the possibility of a novel species, will be conducted. The isolate failed to sporulate after 6 weeks of incubation, despite the use of a range of sporulation-inducing media including Potato Dextrose agar and Tap Water agar at $25^{\circ} \mathrm{C}$ and $35^{\circ} \mathrm{C}$; therefore antifungal susceptibility testing could not be performed. The patient received 6 weeks of IV amphotericin; oral posaconazole was added 3 weeks into therapy, though significant improvement had been 


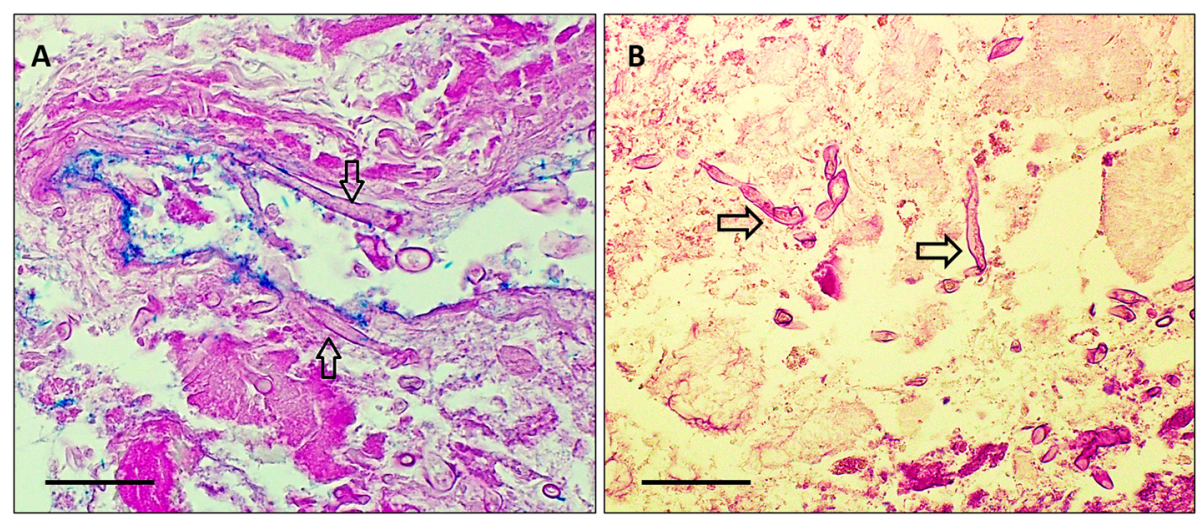

Fig. 3 a Periodic acid-Schiff stain of skin biopsy from the abdominal wall, demonstrating broad, branching, aseptate fungal hyphae invading a blood vessel wall. $\mathbf{b}$. Haematoxylin and eosin stain of a renal biopsy demonstrating broad, aseptate hyphae invading the renal tissue (Bar $20 \mathrm{~mm}$ $A \& B)$

observed following surgical intervention. Posaconazole was given in the form of delayed release tablets $300 \mathrm{mg}$, with a 12-h interval between the first two doses and daily dosing thereafter. His treatment course was complicated by acute kidney injury likely secondary to IV liposomal amphotericin requiring dose reduction, and abnormal liver function tests likely secondary to posaconazole. He was discharged home after 57 days in hospital on oral posaconazole treatment. Therapeutic drug monitoring of posaconazole was performed and levels were considered therapeutic between 1.5 and $3.3 \mathrm{mg} / \mathrm{L}$.

Three months following discharge, he represented with dyspnoea, rhinorrhoea and cough. CT demonstrated consolidation in the lower lobe of the left lung and upper lobe opacities with inflammatory change in the sinuses. Bronchoscopy was unremarkable and fungal culture was negative. This presentation was thought to be secondary to a flare of eosinophilic granulomatosis with polyangiitis in the setting of cessation of his immunosuppression. He received prednisone, which was slowly weaned, and was later switched to mepolizumab (an interleukin-5 inhibitor) for ongoing treatment of EGPA. The patient has received 18 months of posaconazole treatment with no evidence of recurrence of infection, and we remain cautiously optimistic.

\section{Discussion and conclusions}

We describe a case of disseminated mucormycosis secondary to infection with Saksenaea sp. with an unusual presentation and good outcome to date. Genus Saksenaea was first described in 1953, and due to lack of sporulation during growth in the laboratory has been reported rarely. Failure to sporulate on most occasions means that antifungal susceptibility testing cannot be performed, and treatment is usually based on minimum inhibitory concentration (MIC) data for related species of the order Mucorales [7]. There have been reports of higher MICs for Amphotericin B and lower MICs for posaconazole for Saksenaea spp. than for Mucor spp. [8, 9]. In an experimental murine model of disseminated Saksenaea vasiformis infection, posaconazole demonstrated the greatest in vitro activity and was the most effective in prolonging survival in this model [10]. A high dose of $8 \mathrm{mg} / \mathrm{kg}$ liposomal amphotericin B was used in this case with early introduction of posaconazole, however there is limited evidence to guide management of Saksenaea infections. As for other causes of mucormycosis, timely and (where possible) complete surgical debridement is an integral part of management of Saksenaea infections [11].

Despite historical difficulty with laboratory identification, Saksenaea spp. are increasingly reported as the cause of human infection, mostly but not limited to tropical and subtropical areas [12]. Unlike other members of the order Mucorales, Saksenaea infections usually affect immunocompetent hosts, and are often associated with trauma [13]. To our knowledge, there have been six cases of disseminated Saksenaea infection reported; these are summarized in Table 1 [14-19]. Two of these cases had renal involvement, and all six cases had cutaneous lesions. Our case differs in that there has been a favourable outcome to date; survival has been reported in only two cases previously. In those cases, posaconazole was used in combination with IV amphotericin $B$, whereas treatment in all other cases included IV amphotericin B monotherapy. Due to the unusual presentation in our case, diagnosis of invasive fungal infection was delayed until the skin lesions developed and biopsy was obtained. In three of the previously reported disseminated Saksenaea cases, diagnosis was made postmortem highlighting the challenge of diagnosing this rare entity in a timely fashion. It is important to note, four of these diagnoses were made phenotypically and although they were reported as Saksenaea vasiformis, 
Table 1 Reported cases of disseminated Saksenaea spp. infection

\begin{tabular}{|c|c|c|c|c|c|c|c|c|c|c|}
\hline Case & Age & Sex & $\begin{array}{l}\text { Country/ } \\
\text { year }\end{array}$ & Comorbidities & $\begin{array}{l}\text { Mode of } \\
\text { Infection }\end{array}$ & Organism & $\begin{array}{l}\text { Method of } \\
\text { identification }\end{array}$ & $\begin{array}{l}\text { Organ systems } \\
\text { involved }\end{array}$ & Treatment & Outcome \\
\hline 1 [14] & 69 & Female & $\begin{array}{l}\text { United } \\
\text { States of } \\
\text { America } \\
1981\end{array}$ & $\begin{array}{l}\text { Acute myeloid } \\
\text { leukaemia }\end{array}$ & Inhalation & $\begin{array}{l}\text { Saksenaea } \\
\text { sp. }\end{array}$ & Phenotypic & $\begin{array}{l}\text { Cutaneous, } \\
\text { Pulmonary, Renal }\end{array}$ & Nil & Died \\
\hline $2[15]$ & 58 & Male & $\begin{array}{l}\text { Spain } \\
2014\end{array}$ & $\begin{array}{l}\text { Type } 2 \\
\text { Diabetes } \\
\text { Mellitus }\end{array}$ & Trauma & $\begin{array}{l}\text { Saksenaea } \\
\text { vasiformis } \\
\text { complex }\end{array}$ & $\begin{array}{l}\text { Genotypic } \\
\text { (ITS } \\
\text { sequencing) }\end{array}$ & $\begin{array}{l}\text { Cutaneous, Ocular, } \\
\text { Cerebral }\end{array}$ & $\begin{array}{l}\text { Surgical debridement, } \\
\text { IV Amphotericin B }\end{array}$ & Died \\
\hline $3[16]$ & 59 & Male & $\begin{array}{l}\text { Australia } \\
2000\end{array}$ & $\begin{array}{l}\text { Hypertension, } \\
\text { Asthma }\end{array}$ & Inhalation & $\begin{array}{l}\text { Saksenaea } \\
\text { sp. }\end{array}$ & Phenotypic & $\begin{array}{l}\text { Cutaneous, } \\
\text { Cardiac, } \\
\text { Pulmonary, } \\
\text { Thyroid }\end{array}$ & $\begin{array}{l}\text { Surgical debridement, } \\
\text { IV Amphotericin B }\end{array}$ & Died \\
\hline $4[17]$ & 11 & Male & $\begin{array}{l}\text { Australia } \\
2008\end{array}$ & Nil & $\begin{array}{l}\text { Insect } \\
\text { bite }\end{array}$ & $\begin{array}{l}\text { Saksenaea } \\
\text { sp. }\end{array}$ & Phenotypic & Cutaneous, Renal & $\begin{array}{l}\text { Surgical debridement, } \\
\text { IV Amphotericin B, } \\
\text { Posaconazole }\end{array}$ & Survived \\
\hline 5 [18] & 14 & Male & $\begin{array}{l}\text { Iraq } \\
1983\end{array}$ & Nil & Unknown & $\begin{array}{l}\text { Saksenaea } \\
\text { sp. }\end{array}$ & Phenotypic & $\begin{array}{l}\text { Cutaneous, } \\
\text { Pulmonary }\end{array}$ & Nil & Died \\
\hline 6 [19] & 69 & Male & $\begin{array}{l}\text { Singapore } \\
2020\end{array}$ & $\begin{array}{l}\text { Hypertension, } \\
\text { Ischaemic heart } \\
\text { disease }\end{array}$ & Unknown & $\begin{array}{l}\text { Saksenaea } \\
\text { vasiformis } \\
\text { complex }\end{array}$ & $\begin{array}{l}\text { Genotypic } \\
\text { (ITS } \\
\text { sequencing) }\end{array}$ & $\begin{array}{l}\text { Pulmonary, } \\
\text { cutaneous, } \\
\text { retroperitoneal } \\
\text { lesion }\end{array}$ & $\begin{array}{l}\text { IV Amphotericin B, } \\
\text { Posaconazole }\end{array}$ & Survived \\
\hline
\end{tabular}

without DNA sequencing, accurate species identification cannot be confirmed.

None of the previously reported disseminated Saksenaea spp. cases had a history of autoimmune disease or immunosuppressive treatment. In a series of cases of mucormycosis from Australia [20], 9/74 (12\%) had a history of an autoimmune or rheumatologic condition such as systemic lupus erythematosus or rheumatoid arthritis, and all but one had received prior treatment with corticosteroids. The infecting fungal species were identified in 7/9, and included Rhizopus spp., Rhizomucor spp. and Mucor spp.; all 9 patients died. Despite a history of EPGA with immunosuppressive treatment, our patient survived. We attribute the good outcome to aggressive surgical debridement and combination antifungal treatment with liposomal amphotericin and posaconazole.

In summary, species of the genus Saksenaea are emerging as fungal pathogens with worldwide distribution, causing mucormycosis in both immunocompetent and immunocompromised hosts. Making the diagnosis can be challenging due to diverse clinical manifestations and difficulty with phenotypic identification, and susceptibility information is often elusive. We describe an unusual case of disseminated infection with this organism, associated with a good outcome 18 months after presentation.

\section{Abbreviations}

BLASTn: Nucleotide Basic Local Alignment Search Tool; CT: Computed Tomography; DNA: Deoxyribonucleic acid; EGPA: Eosinophilic granulomatosis with polyangiitis; ISHAM: International Society of Human and Animal Mycology; ITS: Internal Transcribed Spacer; IV: Intravenous; KOH: Potassium hydroxide; MIC: Minimum Inhibitory Concentration; NCBI: National Center for Biotechnology Information; spp.: species'; sp.: species

\section{Acknowledgements}

We would like to acknowledge the valuable contributions of Dr. Patrick Bade, Dr. Henry Duncan and our colleagues in the Departments of Respiratory Medicine and Nephrology for the care of the patient.

\section{Authors' contributions}

$N D, E M, J D, V T, K C$ and SL were involved in the clinical care of the patient. FF performed the histological examination of the skin biopsy and renal tissue and RB was involved in the preliminary microbiological diagnosis. LC and SK were involved in identification of the fungal isolate at the reference laboratory. ND wrote the drafts of the manuscript. All authors read, edited and approved the final manuscript.

\section{Funding}

There was no finding for this publication.

\section{Availability of data and materials}

Data sharing is not applicable to this article as no datasets were generated or analysed during the current study.

Ethics approval and consent to participate

Not applicable.

\section{Consent for publication}

The patient has given his verbal and written consent for publication of this report. (Form available on request).

\section{Competing interests}

The authors declare that they have no competing interests.

\section{Author details}

'Division of Medicine, Royal Darwin Hospital, Darwin, Australia. ${ }^{2}$ Sullivan and Nicolaides Pathology, Brisbane, Australia. ${ }^{3}$ Department of Pathology, Royal Darwin Hospital, Darwin, Australia. ${ }^{4}$ Global and Tropical Health Division, Charles Darwin University, Menzies School of Health Research, Darwin, 
Australia. ${ }^{5}$ National Mycology Reference Centre, Microbiology and Infectious Diseases, SA Pathology, Frome Road, Adelaide, South Australia, Australia.

Received: 21 December 2019 Accepted: 29 September 2020

Published online: 14 October 2020

\section{References}

1. Gomes MZ, Lewis RE, Kontoyiannis DP. Mucormycosis caused by unusual mucormycetes, non-Rhizopus, -Mucor, and -Lichtheimia species. Clin Microbiol Rev. 2011;24(2):411-45.

2. Saksena SB. A new genus of the Mucorales. Mycologia. 1953:45(3):426-36.

3. Walther G, Wagner L, Kurzai O. Updates on the Taxonomy of Mucorales with an Emphasis on Clinically Important Taxa. J Fungi (Basel). 2019;5(4):106.

4. Labuda R, Bernreiter A, Hochenauer D, Schuller C, Kubatova A, Strauss J, et al. Saksenaea dorisiae sp. nov., a new opportunistic pathogenic fungus from Europe. Int. J Microbiol. 2019;2019:6253829.

5. Alvarez E, Garcia-Hermoso D, Sutton DA, Cano JF, Stchigel AM, Hoinard D, et al. Molecular phylogeny and proposal of two new species of the emerging pathogenic fungus Saksenaea. J Clin Microbiol. 2010;48(12):4410-6.

6. Coordinators NR. Database resources of the National Center for biotechnology information. Nucleic Acids Res. 2016;44(D1):D7-D19.

7. Ellis DH, Kaminski GW. Laboratory identification of Saksenaea vasiformis: a rare cause of zygomycosis in Australia. Sabouraudia. 1985;23(2):137-40.

8. Blanchet D, Dannaoui E, Fior A, Huber F, Couppie P, Salhab N, et al. Saksenaea vasiformis infection, French Guiana. Emerg Infect Dis. 2008;14(2):342-4.

9. Sun ON, Fothergill AW, McCarthy DI, Rinaldi MG, Graybill JR. In vitro activities of posaconazole, itraconazole, voriconazole, amphotericin B, and fluconazole against 37 clinical isolates of zygomycetes. Antimicrob Agents Chemother. 2002;46(5):1581-2.

10. Salas V, Pastor FJ, Calvo E, Sutton D, Garcia-Hermoso D, Mayayo E, et al. Experimental murine model of disseminated infection by Saksenaea vasiformis: successful treatment with posaconazole. Med Mycol. 2012;50(7):710-5.

11. Spellberg B, Ibrahim AS. Recent advances in the treatment of mucormycosis. Curr Infect Dis Rep. 2010;12(6):423-9.

12. Prakash $\mathrm{H}$, Chakrabarti A. Global Epidemiology of Mucormycosis. J Fungi (Basel). 2019;5(1):26.

13. Samaras K, Markantonatou AM, Karapiperis D, Digonis P, Kartalis N, Kostogloudis $N$, et al. Saksenaea vasiformis infections: a case of an immunocompetent adult after mild injury and a literature review. J Mycol Med. 2019;29(3):260-4.

14. Torell J, Cooper BH, Helgeson NG. Disseminated Saksenaea vasiformis infection. Am J Clin Pathol. 1981;76(1):116-21.

15. Gómez-Camarasa C, Rojo-Martín MD, Miranda-Casas C, Alastruey-Izquierdo A, Aliaga-Martínez L, Labrador-Molina JM, et al. Disseminated infection due to Saksenaea vasiformis secondary to cutaneous Mucormycosis. Mycopathologia. 2014;177(1):97-101.

16. Solano TAB, Tambosis E, Mann S, Gottlieb T. Disseminated Mucormycosis due to Saksenaea vasiformis in an Immunocompetent adult. Clin Infect Dis. 2000;30:942-3.

17. Trotter DJ, Gonis G, Cottrill E, Coombs C. Disseminated Saksenaea vasiformis in an immunocompetent host. Med J Aust. 2008;189(9):519-20.

18. Hay RCC, Marshall W, Rees B, Pincott J. Disseminated zygomycosis (mucormycosis) caused by Saksenaea vasiformis. J Infect. 1983;7:162-5

19. Liang En W, Seow Yen T, Ai Ling T, Yen Ee T, Sze Hwa T, Chun AC, et al. Disseminated Mucormycosis due to Saksenaea vasiformis complex in an Immunocompetent adult with sustained response to Posaconazole treatment. Mycopathologia. 2020;185(3):577-81.

20. Kennedy KJ, Daveson K, Slavin MA, van Hal SJ, Sorrell TC, Lee A, et al. Mucormycosis in Australia: contemporary epidemiology and outcomes. Clin Microbiol Infect. 2016;22(9):775-81.

\section{Publisher's Note}

Springer Nature remains neutral with regard to jurisdictional claims in published maps and institutional affiliations.

Ready to submit your research? Choose BMC and benefit from:

- fast, convenient online submission

- thorough peer review by experienced researchers in your field

- rapid publication on acceptance

- support for research data, including large and complex data types

- gold Open Access which fosters wider collaboration and increased citations

- maximum visibility for your research: over $100 \mathrm{M}$ website views per year

At BMC, research is always in progress.

Learn more biomedcentral.com/submissions 